\title{
Adenovirus-mediated Gene Transfer into Normal Rabbit Arteries Results in Prolonged Vascular Cell Activation, Inflammation, and Neointimal Hyperplasia
}

\author{
Kurt D. Newman, ${ }^{\S}$ Peter F. Dunn, ${ }^{\star}$ Jennie W. Owens, * Andrew H. Schulick, * Renu Virmani, ${ }^{*}$ Galina Sukhova," \\ Peter Libby," and David A. Dichek*1 \\ * Molecular Hematology Branch, National Heart, Lung, and Blood Institute, Bethesda, Maryland 20892; ${ }^{\ddagger}$ Armed Forces Institute of \\ Pathology, Washington, D.C. 20307; ' Department of Surgery, Children's Hospital, Washington, D.C. 20010; "Vascular Medicine and \\ Atherosclerosis Unit, Cardiovascular Division, Department of Medicine, Brigham and Women's Hospital, Boston, Massachusetts 02115; \\ and 'Gladstone Institute of Cardiovascular Disease, and Daiichi Research Center, University of California, San Francisco, California \\ 94141-9100
}

\begin{abstract}
Adenovirus vectors are capable of high efficiency in vivo arterial gene transfer, and are currently in use as therapeutic agents in animal models of vascular disease. However, despite substantial data on the ability of viruses to cause vascular inflammation and proliferation, and the presence in current adenovirus vectors of viral open reading frames that are translated in vivo, no study has examined the effect of adenovirus vectors alone on the arterial phenotype. In a rabbit model of gene transfer into a normal artery, we examined potential vascular cell activation, inflammation, and neointimal proliferation resulting from exposure to replication-defective adenovirus.

Exposure of normal arteries to adenovirus vectors resulted in: $(a)$ pronounced infiltration of $T$ cells throughout the artery wall; $(b)$ upregulation of intercellular adhesion molecule-1 and vascular cell adhesion molecule- 1 in arterial smooth muscle cells; $(c)$ neointimal hyperplasia. These findings were present both 10 and $30 \mathrm{~d}$ after gene transfer, with no evidence of a decline in severity over time.

Adenovirus vectors have pleiotropic effects on the arterial wall and cause significant pathology. Interpretation of experimental protocols that use adenovirus vectors to address either biological or therapeutic issues should take these observations into account. These observations should also prompt the design of more inert gene transfer vectors. (J. Clin. Invest. 1995. 96:2955-2965.) Key words: adenoviruses $\bullet$ arteries $\cdot$ gene transfer $\cdot$ inflammation $\cdot$ rabbits
\end{abstract}

\section{Introduction}

In vivo gene transfer into the arterial wall is a powerful experimental approach by which one may both investigate the function of individual genes in the development of arterial pathology (1) and attempt to manipulate the arterial wall for therapeutic

Address correspondence to David A. Dichek, Gladstone Institute of Cardiovascular Disease, P.O. Box 419100, San Francisco, CA 94141-9100. Phone: 415-826-7500; FAX: 415-285-5632; E-mail: david_dichek@quickmail.ucsf.edu

Received for publication 13 March 1995 and accepted in revised form 8 September 1995.

J. Clin. Invest.

(C) The American Society for Clinical Investigation, Inc. 0021-9738/95/12/2955/11 \$2.00

Volume 96, December 1995, 2955-2965 purposes (2-5). Recently, replication-defective adenovirus has become the arterial gene transfer vector-of-choice for a majority of investigators (6-11). The advantages of adenovirus as an arterial gene transfer vector include the ease of preparation of high-titer virus $\left(>10^{10} \text { plaque forming units [pfu }\right]^{1}$ per $\mathrm{ml}$ ) (12), and the ability of adenovirus to infect nondividing cells with high efficiency (13), including the endothelial cells and smooth muscle cells (SMC) of the arterial wall $(6,7,9,14)$. A potential disadvantage of adenovirus as an arterial gene transfer vector is that, despite the $\mathrm{E} 1$ gene deletion that renders the virus defective for replication, the remaining virus genome contains numerous open reading frames encoding viral proteins (12). Expression of viral proteins by transduced cells elicits both humoral and cellular immune responses in animals (15-18) and could conceivably provoke arterial cell activation, inflammation, and proliferation, as has been reported for wild-type viruses (19).

Despite the potential for adenovirus vectors to produce deleterious effects on the arterial wall, no study has yet examined the effects of these vectors on the arterial phenotype. Primary effects of adenovirus vectors (i.e., effects unrelated to any inserted transgene) would be a major concern in the design of biological experiments and could also confound the design and interpretation of therapeutic experiments. For example, in arterial gene transfer experiments with a therapeutic endpoint (24 ), it is generally perceived that the adenovirus acts as an inert carrier of a therapeutic gene, and that the achievement of a beneficial endpoint is neither moderated nor prevented by independent effects of the vector. Certainly, widely held current views of adenovirus vectors do not envisage the possibility that they could have primarily detrimental effects on the arterial wall $(20,21)$.

In this study, we investigated the effects of adenovirusmediated gene transfer per se on arterial cell activation, mononuclear leukocyte infiltration, and intimal proliferation. To accomplish this objective, we infused adenovirus or control solutions into surgically isolated, normal rabbit femoral arteries. The arteries were harvested at time points up to $30 \mathrm{~d}$ after virus infusion and assayed for: $(a)$ expression of intercellular adhesion molecule-1 (ICAM-1), vascular cell adhesion molecule-1 (VCAM-1), and MHC-II antigens (all markers of vascular cell activation $[22,23]) ;(b)$ presence of inflammatory $\mathrm{T}$

1. Abbreviations used in this paper: $\beta$-Gal, $\beta$-galactosidase; ICAM-1, intercellular adhesion molecule-1; pfu, plaque forming unit; SMC, smooth muscle cell; VCAM-1, vascular cell adhesion molecule-1; XGal, 5-bromo-4-chloro-3-indolyl- $\beta$-D-galactopyranoside. 
cells and macrophages; and (c) development of neointimal hyperplasia.

\section{Methods}

Adenovirus vectors. We used two adenovirus vectors: Av1LacZ4 and Av1Nul2. Both vectors were provided by Dr. Bruce Trapnell (Genetic Therapy Incorporated, Gaithersburg, MD). The construction of Av1LacZ4, a replication-defective adenovirus containing a nuclear-targeted Escherichia coli $\beta$-galactosidase ( $\beta$-Gal) transgene, has been described (7). Av1Nul2 is also a replication-defective E1/E3-deleted adenovirus that is essentially identical to Av1LacZ4, except that the genome of Av1Nul2 does not contain a nuclear-targeted $\beta$-Gal expression cassette. We used the latter vector as a control to elucidate whether effects observed with Av1LacZ4 were due to exposure to replication-defective adenovirus or to the $\beta$-Gal transgene. Viral stocks were generated by infection of 293 cells and were concentrated by two rounds of cesium chloride ultracentrifugation (12). Cesium-banded virus stocks were dialyzed against $10 \mathrm{mM}$ Tris $\mathrm{pH} 7.4,1 \mathrm{mM} \mathrm{MgCl}_{2}$, and $10 \%$ glycerol; they were then aliquotted, and stored over liquid nitrogen until use. The concentrations of stocks of Av1LacZ4 and Av1Nul2 were $2 \times 10^{11}$ and $8 \times 10^{10} \mathrm{pfu} / \mathrm{ml}$, respectively, as determined by plaque titration on 293 cells.

For animal experiments, frozen vector stocks were thawed and used within $30 \mathrm{~min}$. Av1LacZ4 stock was diluted 1:10 to a final concentration of $2 \times 10^{10} \mathrm{pfu} / \mathrm{ml}$ in DME (Biofluids Inc., Rockville, MD) containing $1 \mathrm{mg} / \mathrm{ml}$ rabbit serum albumin (Sigma Chemical Co., St. Louis, MO). Av1Nul2 stock was diluted 1:4 to achieve the same final concentration of $2 \times 10^{10} \mathrm{pfu} / \mathrm{ml}$. We infused control vessels with two types of nonvirus-containing solution: $(a)$ the "viral diluent"' (DME with $1 \mathrm{mg}$ / $\mathrm{ml}$ rabbit albumin); $(b)$ the "virus storage buffer" (10 mM Tris $\mathrm{pH}$ $7.4,1 \mathrm{mM} \mathrm{MgCl} 2,10 \%$ glycerol) diluted either $1: 10$ or $1: 4$ with viral diluent, to match the concentration of virus storage buffer in the diluted adenovirus preparations.

Animal surgery. All animal procedures were approved by the Animal Care and Use Committee of the National Heart, Lung, and Blood Institute. Adult New Zealand White rabbits (Hazleton Research Products, Inc., Denver, PA), weighing 3-5 kg, were used. Anesthesia was induced with ketamine (Fort Dodge Laboratories Inc., Fort Dodge, IA) $8 \mathrm{mg}$ / kg intravenously and xylazine (Miles Inc., Shawnee Mission, KS) 3 $\mathrm{mg} / \mathrm{kg}$ intramuscularly. After endotracheal intubation, glycopyrrolate 0.1-0.2 mg (Fort Dodge Laboratories, Fort Dodge, IA) was administered intramuscularly and anesthesia was maintained with inhaled isoflurane 1-2\% (Ohmeda, Madison, WI). Enrofloxacin 2.27\% (0.2 $\mathrm{cm}^{3} / \mathrm{kg}$ ) was injected subcutaneously b.i.d. for $3 \mathrm{~d}$ for infection prophylaxis. A total of 59 rabbits received adenovirus infusion in one femoral artery and a control infusion in the contralateral femoral artery. Two rabbits received bilateral femoral artery infusions of UV-inactivated adenovirus ( see below). One additional rabbit underwent balloon injury of the iliac artery to provide a positive control for immunohistochemistry experiments, and two rabbits underwent bilateral femoral infusion of control solutions, with pressure monitoring (see below). These latter three rabbits received no virus infusion.

Vascular surgery was performed with the aid of a Zeiss Universal S3 operating microscope (Oberkobern, Germany) at 2-10 times magnification (Fig. 1). Both superficial femoral arteries were exposed and isolated circumferentially from the inguinal ligament to the knee; all side branches were ligated. Topical lidocaine 1\% (Abbott Laboratories, North Chicago, IL) was applied to each artery as needed (typically twice) to relieve spasm. Rabbits were given $100 \mathrm{U} / \mathrm{kg}$ of intravenous heparin (Elkins-Sinn, Inc., Cherry Hill, NJ). To obtain an isolated arterial segment for gene transfer, the superficial femoral artery was first controlled proximally with two microvascular clips. A needle hole was created between the two clips with a 27 -gauge needle to provide a site of egress for infused solutions. The popliteal artery was then occluded with a microvascular clip and distal control of the saphenous artery at the knee was obtained with a silk tie and a microvascular clip. An

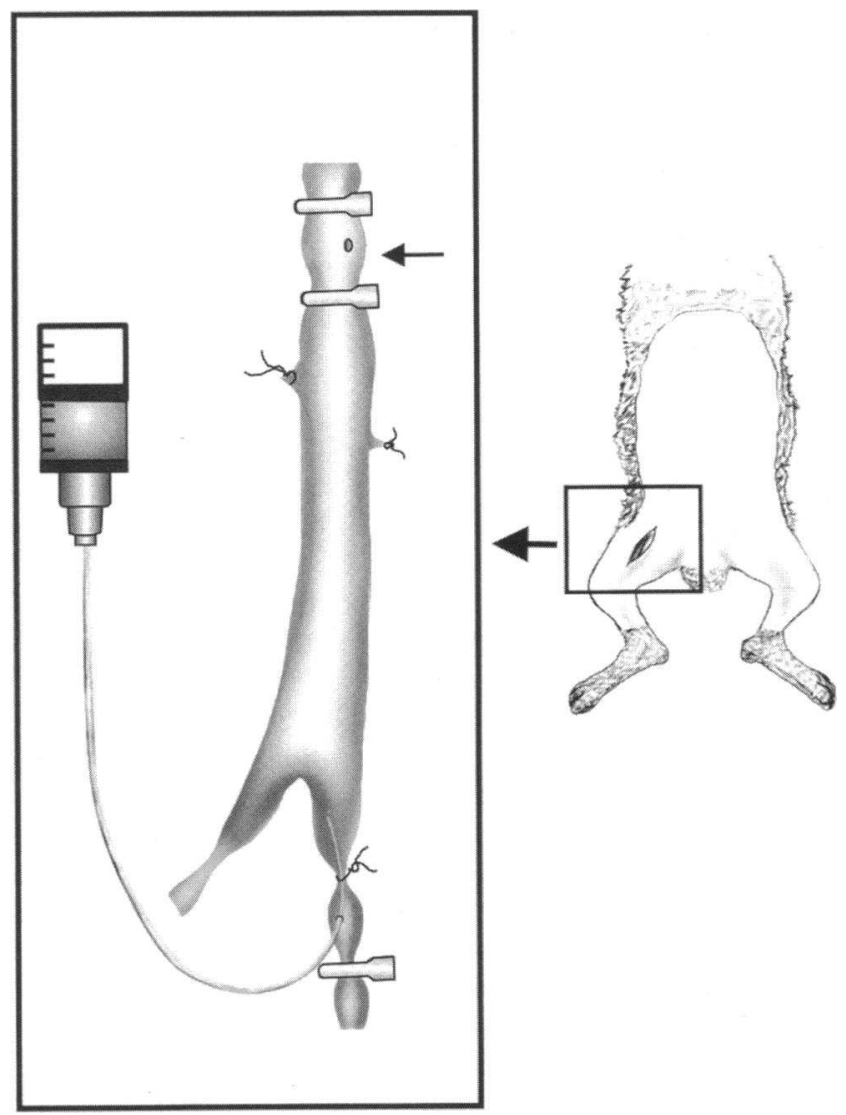

Figure 1. Surgical protocol for isolation of rabbit femoral arteries and infusion of adenovirus. With the rabbit in the supine position (right), each superficial femoral artery is isolated between surgical clips. The infusion catheter, attached to a syringe (not to scale), is shown in the saphenous artery and is secured with a tie. The needle hole (arrow) between the proximal clips permits flushing of the vessel lumen and infusion of the virus, without leakage or mixture with arterial blood, and with minimal vessel collapse.

arteriotomy was made between the tie and the clip and a Silastic catheter ( 0.012 inches inner diameter, 0.025 inches outer diameter; Reed Plastics, Rockville, MD) was introduced into the lumen. The isolated vessel was flushed via the catheter with $\sim 0.2-0.5 \mathrm{ml}$ of the appropriate control solution, removing all blood from within the vessel lumen via the proximal needle hole. Care was taken to avoid vessel collapse or introduction of air that could result in endothelial injury. The catheter was then withdrawn and replaced with another catheter prefilled with either the experimental virus or a control solution. All solutions were infused so as to flush the medium through the needle hole, followed by reapplication of the proximal femoral clip to occlude the segment and continued infusion of a volume of solution adequate to distend the vessel slightly. Approximately $200 \mu \mathrm{l}$ of infusate was required to accomplish flushing, filling, and distension of the artery. The infused solutions were allowed to dwell in situ for $20 \mathrm{~min}$. At the conclusion of this incubation, the proximal needle hole was repaired with a single 10-0 suture (Ethicon, Somerville, $\mathrm{NJ}$ ). The catheter was removed and the saphenous artery was ligated. Flow was reestablished by removing the clips on the proximal superficial femoral and deep popliteal arteries. The wounds were closed, and animals recovered from anesthesia. In two additional animals, we measured the infusion pressure during bilateral infusion of control solutions by using a pressure transducer connected to the infusion catheter. Intraluminal pressure was monitored with a physiologic recorder (Gould Electronics, College Park, MD). The infusion pressure 
varied between 80 and $100 \mathrm{mmHg}$ during the 20-min infusions in all four vessels that were tested.

To obtain a positive control vessel for use in immunohistochemical experiments, we performed balloon injury of the iliac artery in one rabbit (22). $5 \mathrm{~d}$ later, this animal was injected intravenously with Evans Blue dye. The animal was then killed, the iliac artery harvested, and the area of injury identified as the segment with Evans Blue staining. The blue-stained segment was excised, snap-frozen, and processed as described below for immunohistochemical analysis.

To begin to investigate the species potential specificity of our findings in this rabbit model, we also examined sections from uninjured rat carotid arteries transduced with Av1LacZ4 at $3 \times 10^{10} \mathrm{pfu} / \mathrm{ml}$ and harvested $14(n=4)(24)$ and $28 \mathrm{~d}(n=5)$ after gene transfer. These sections were examined both for neointima formation and for the presence of $T$ cells, using techniques described elsewhere $(24,25)$.

Harvesting of vessels. Vessels were harvested at 3,10, and $30 \mathrm{~d}$ after gene transfer. Vessels were either perfusion-fixed in situ or were snap-frozen for immunohistochemical analysis. Perfusion fixation was carried out as follows: general anesthesia was achieved, the abdominal aorta was exposed through a midline incision, and $100 \mathrm{U} / \mathrm{kg}$ of heparin were given intravenously. The aorta was ligated, and a 19-gauge catheter introduced distal to the ligation. A venotomy was made in the inferior vena cava. $500 \mathrm{ml}$ of Ringer's Lactate were infused into the distal abdominal aorta until the caval effluent was clear. The animal was then killed by intravenous overdose of potassium chloride. For vessels undergoing histochemical staining for $\beta$-Gal, $1,500 \mathrm{ml}$ of $2 \%$ formaldehyde (Mallinckrodt, Paris, KY), $0.2 \%$ glutaraldehyde (Sigma Chemical Co.) in PBS was perfused at $80 \mathrm{mmHg}$ via the distal aorta. For vessels undergoing histologic analysis of intimal/medial area ratios, $1,000 \mathrm{ml}$ of $10 \%$ formaldehyde in PBS was perfused at $80 \mathrm{mmHg}$ through the distal aorta. After the perfusion fixation, a $1.5-\mathrm{cm}$ segment of each common femoral artery was excised, and incubated further for $2 \mathrm{~h}$ in the appropriate fixative.

Arterial samples for frozen sections were obtained as follows: general anesthesia was achieved and the common femoral arteries and abdominal aorta were exposed. The animal was injected intravenously with $100 \mathrm{U} / \mathrm{kg}$ heparin and killed with an intravenous overdose of potassium chloride. Segments of the abdominal aorta and of each common femoral artery, all approximately $1 \mathrm{~cm}$ in length, were harvested and rinsed with Ringer's Lactate. The segments were then embedded by immersion in optimal cutting temperature compound (Tissue Tek II; Miles Laboratories, Elkhart, IN) followed by freezing in isopentane. Frozen sections (6- $\mu \mathrm{m}$ thickness) were cut on a cryostat, air-dried, and stored at $-80^{\circ} \mathrm{C}$ until used in immunohistochemical studies.

Histochemical staining for $\beta$-Gal expression. 16 rabbits were infused with Av1LacZ4 on one side and viral diluent on the contralateral side. Vessels were harvested at $3(n=5), 10(n=4)$, and $30 \mathrm{~d}(n$ $=7)$. The arterial segments were washed in PBS and incubated in 5bromo-4-chloro-3-indolyl- $\beta$-D-galactopyranoside (X-Gal) for $2 \mathrm{~h}$ at $3^{\circ} \mathrm{C}$. The vessel segments were then washed in PBS, cut longitudinally, and examined for evidence of $\beta$-Gal expression. These stained vessel segments were each divided into three segments of $\sim 3$-mm length and embedded in paraffin. Three cross sections $(5-\mu \mathrm{m}$ thick and spaced at least $50 \mu \mathrm{m}$ apart) were cut from each segment and counterstained with nuclear fast red (nine sections per vessel). These sections were examined with light microscopy, and the numbers of X-Gal-stained luminal endothelial cells, X-Gal-stained medial SMC, and total luminal endothelial cells (both stained and unstained) were counted. From these data, we calculated percentages of luminal endothelial cells that were transduced, as well as the percentages of total transduced cells that were endothelial cells for each vessel. The media of these normal rabbit femoral arteries, harvested $3 \mathrm{~d}$ after gene transfer, were identified as containing essentially only SMC by staining of frozen sections with an antibody to SMC actin (26) (data not shown). Luminal cells were identified as endothelial cells by morphology (flattened with prominent nuclei) and by luminal location.

$\beta$-Gal expression was also detected in frozen sections by fixation of sections with $2 \%$ formaldehyde, $0.2 \%$ glutaraldehyde for $5 \mathrm{~min}$ fol- lowed by a rinse with PBS and exposure of fixed sections to X-Gal staining solution for $60 \mathrm{~min}$ at $37^{\circ} \mathrm{C}$

Immunohistochemistry. One group of rabbits $(n=11)$ was infused with Av1LacZ4 on one side and virus diluent on the contralateral side. Vessels were harvested at $3(n=4), 10(n=4)$, and $30 \mathrm{~d}(n=3)$. Because of a concern that the viral diluent alone might not be the most suitable control for the diluted viral stocks, a second group of rabbits $(n=4)$ was infused with Av1LacZ4 in one femoral artery and diluted virus storage buffer (see above) on the contralateral side. Vessels from this group of rabbits were harvested at $30 \mathrm{~d}$. To control for effects attributable to the $\beta-\mathrm{Gal}$ transgene, a third group of rabbits $(n=4)$ was infused with Av1Nul2 in one femoral artery and with diluted virus storage buffer on the contralateral side. Vessels in this group of rabbits were harvested at $30 \mathrm{~d}$.

To obtain vessel cross sections for immunohistochemistry, serial cryostat sections were cut from each block. The block for each rabbit contained sections of aorta (unmanipulated), of the femoral artery exposed to adenovirus, and of the femoral artery exposed to the control solution. The sections were air-dried, fixed in acetone at $-20^{\circ} \mathrm{C}$ for 5 min, incubated with PBS containing $0.3 \%$ hydrogen peroxide to reduce endogenous peroxidase activity, preincubated with $5 \%$ normal horse serum to prevent nonspecific binding of antibodies, and then incubated with primary antibodies diluted in $10 \%$ horse serum (Vector Laboratories, Burlingame, CA) at room temperature for $\mathbf{9 0} \mathrm{min}$. After washing with Tris-buffered saline $(0.05 \mathrm{M}$ Tris, $\mathrm{pH} 7.6)$ containing $2 \%$ horse serum, species-appropriate biotinylated secondary antibodies were applied followed by avidin-biotin peroxidase complex (Vectastain ABC Elite kit; Vector Laboratories). Antibody binding was visualized with 3-amino-9-ethyl carbazole (Vector Laboratories). Sections were counterstained with hematoxylin. Omission of primary antibodies served as a negative control for each antibody. Positive control sections (taken from the balloon-injured rabbit iliac artery) were also tested.

Immunohistochemical staining was performed with a series of five monoclonal antibodies: mAb Rb1/9 (recognizing rabbit VCAM-1); mAb Rb2/3 (recognizing rabbit ICAM-1); mAb RAM-11 recognizes a cytoplasmic antigen protein expressed by rabbit alveolar macrophages (Dako Corp., Carpinteria, CA); mAb 2C4 binds to a framework determinant of the alpha chain of a rabbit MHC-II antigen (RLA-DR); and mAb L-11/135 detects a 120-kD glycoprotein determinant present on rabbit thymocytes and peripheral $\mathrm{T}$ cells (27). Each antibody was applied to three histologic sections selected at random from along the length of each artery. The sections were evaluated with light microscopy and graded for primary antibody reactivity by two independent observers, each of whom was blinded to the identity of the sections. Antibody reactivity on each section was scored with the aid of a semiquantitative scale of 0 to 4 in which: $0=$ no staining; 1 = staining barely visible at low $(\times 100)$ power; $2=$ diffuse faint or focal staining clearly visible at low power; $3=$ moderate intensity with multifocal staining; 4 $=$ intense, diffuse staining. The scores of the 2 observers were highly correlated $\left(r^{2}=0.96 ; P<0.0001\right)$. For convenience, therefore, scores from only one observer were used for calculation of vessel mean scores. To permit a nonparametric statistical analysis of data that was not expected to be normally distributed, all of the vessels harvested at each time point and stained with a given antibody were also ranked in order of the intensity of staining.

Infusion of UV-inactivated adenovirus. To test the hypothesis that improvements in adenovirus vector design that decrease viral gene expression will also decrease the level of vascular cell activation after arterial gene transfer, we infused UV-inactivated Av1LacZ4 into four femoral arteries in two rabbits. Before infusion, aliquots of Av1LacZ4 were exposed to $260 \mathrm{~nm} \mathrm{UV}$ light at a distance of $1 \mathrm{~cm}$ for $200 \mathrm{~s}$. This treatment was confirmed to result in a significant decrease in virus gene expression after infection of cells in vitro with relative preservation of virus protein function in vitro as measured by ability of the UV-inactivated virus to enhance the efficiency of plasmid cotransfection (28) (data not shown). Aliquots of UV-inactivated Av1LacZ4 used for in vivo experiments were of the same "prep" as was used for the experiments with non-UV-inactivated virus. 

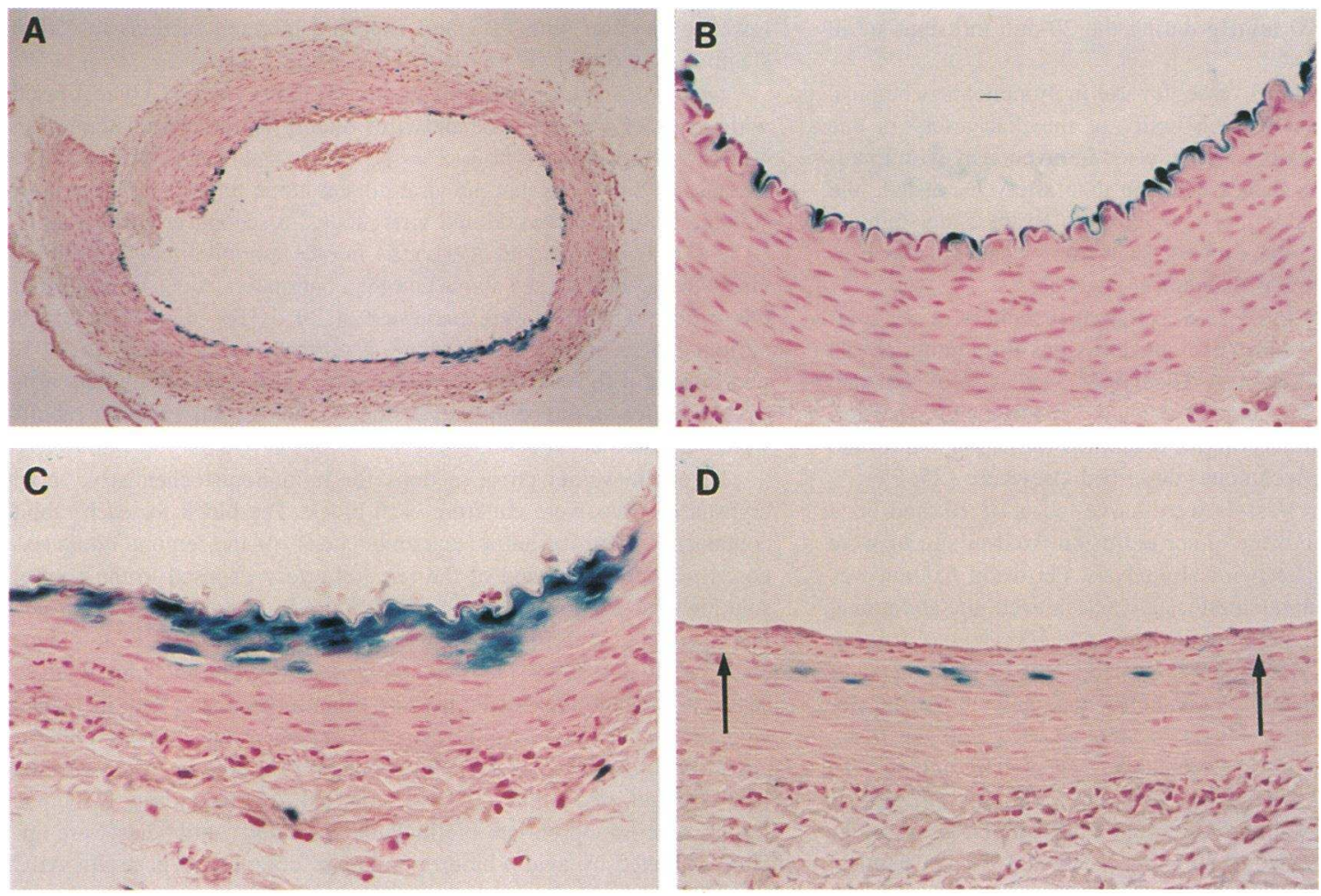

Figure 2. Histological localization of transduced femoral arterial cells. Photomicrographs $A-C$ are of sections harvested $3 \mathrm{~d}$ after infusion of Av1LacZ4, stained with X-Gal, and counterstained with nuclear fast red. $(A)$ Low power view shows recombinant gene expression in both endothelial and medial SMC. $(B)$ High power view of area of efficient, endothelial-specific gene transfer. $(C)$ High power view of area of denuded endothelium and focal medial SMC gene transfer. Three cells in the adventitia also express the recombinant gene. $(D)$ Section from an artery harvested $10 \mathrm{~d}$ after infusion with AvlLacZ4, also stained with X-Gal and nuclear fast red. A neointima is present above the internal elastic lamina (arrows). Several medial SMC stain positively with X-Gal. Original magnifications: 25 (A); 100 (B-D).

Vessel morphometry. 12 rabbits were infused with Av1LacZ4 on one side and viral diluent on the contralateral side. Vessels were harvested at $10(n=6)$ and $30 \mathrm{~d}(n=6)$. A second group of rabbits $(n=7)$ was infused with Av1LacZ4 on one side and virus storage buffer (diluted 1:10 with virus diluent) on the contralateral side. This group of rabbits underwent vessel harvest only at $30 \mathrm{~d}$. A third group of rabbits $(n$ $=5$ ) was infused with Av1Nul2 on one side and virus storage buffer (diluted 1:4 with virus diluent) on the contralateral side. Vessel harvest for this third group was again performed at $30 \mathrm{~d}$ only.

To obtain sections for morphometric analysis, the perfusion-fixed vessels were divided into segments of 2-mm length and embedded in paraffin. Cross sections (5- $\mu$ m thick) were cut from each segment and stained with Movat's pentachrome stain. Computerized morphometric measurements of intimal area, medial area, and intimal/medial area ratio were made using a computerized morphometric imaging system (IPLab ${ }^{\text {TM }}$ Image Analysis Software, Version 2.5, Vienna, VA) using an Olympus $\mathrm{BH} 2$ microscope at $40 \times$ and Sony $3 \mathrm{CCD}$ color video camera. Four randomly-chosen histologic sections from each vessel were analyzed and used to calculate a mean intimal/medial area ratio for each vessel.

Statistics. Mean intimal/medial area ratios for groups of experimental and control vessels were compared using a two-tailed unpaired Student's $t$ test. Ranked staining intensities assigned from the immunohistochemical studies were compared by nonparametric analysis. A MannWhitney U statistic (29) was calculated to examine the null hypotheses (using a two-tailed $\alpha$ of 0.05 ) that: ( $a$ ) the adenovirus-exposed vessels had the same degree of staining as the control vessels; and $(b)$ the vessels infused with UV-inactivated adenovirus had the same degree of staining as vessels infused with non-UV-inactivated virus. Data are presented as mean $\pm \mathrm{SD}$.

\section{Results}

Vessel patency, distribution, and duration of recombinant gene expression after infusion of Av1 LacZ4. All vessels harvested 3 $\mathrm{d}$ after gene transfer were patent. On both gross and microscopic examination, five of five experimental arteries stained for recombinant $\beta$-Gal. As expected, none of the control arteries stained positively. $\beta$-Gal activity was detected primarily in luminal endothelial cells and in medial SMC (Fig. 2, $A-C$ ). A small number of transduced cells were seen in the adventitia (Fig. $2 C$ ). The total number of transduced luminal endothelial cells per histologic cross section of Av1LacZ4-infused arteries was $37.3 \pm 11.5$. The total number of luminal endothelial cells was $103 \pm 22.1$, and the overall percentage of the total luminal endothelial cells that had been transduced was $36 \pm 6 \%$. The number of transduced SMC per histologic section was $11.4 \pm 6$, representing $25 \pm 28 \%$ of total transduced cells, with the remainder $(75 \pm 29 \%)$ identified as endothelial. A small amount of endothelial denudation was observed in both control and Av1LacZ4-transduced vessels, and this finding was correlated with the presence of subjacent transduced SMC. This animal model is therefore one of high efficiency, predominantly endothelial gene transfer into a minimally injured peripheral artery.

All vessels harvested $10 \mathrm{~d}$ after gene transfer were patent. On gross examination, neither experimental nor paired control arteries $(n=4)$ stained positively for recombinant gene expression. On microscopic examination, four of four experimental 
Virus
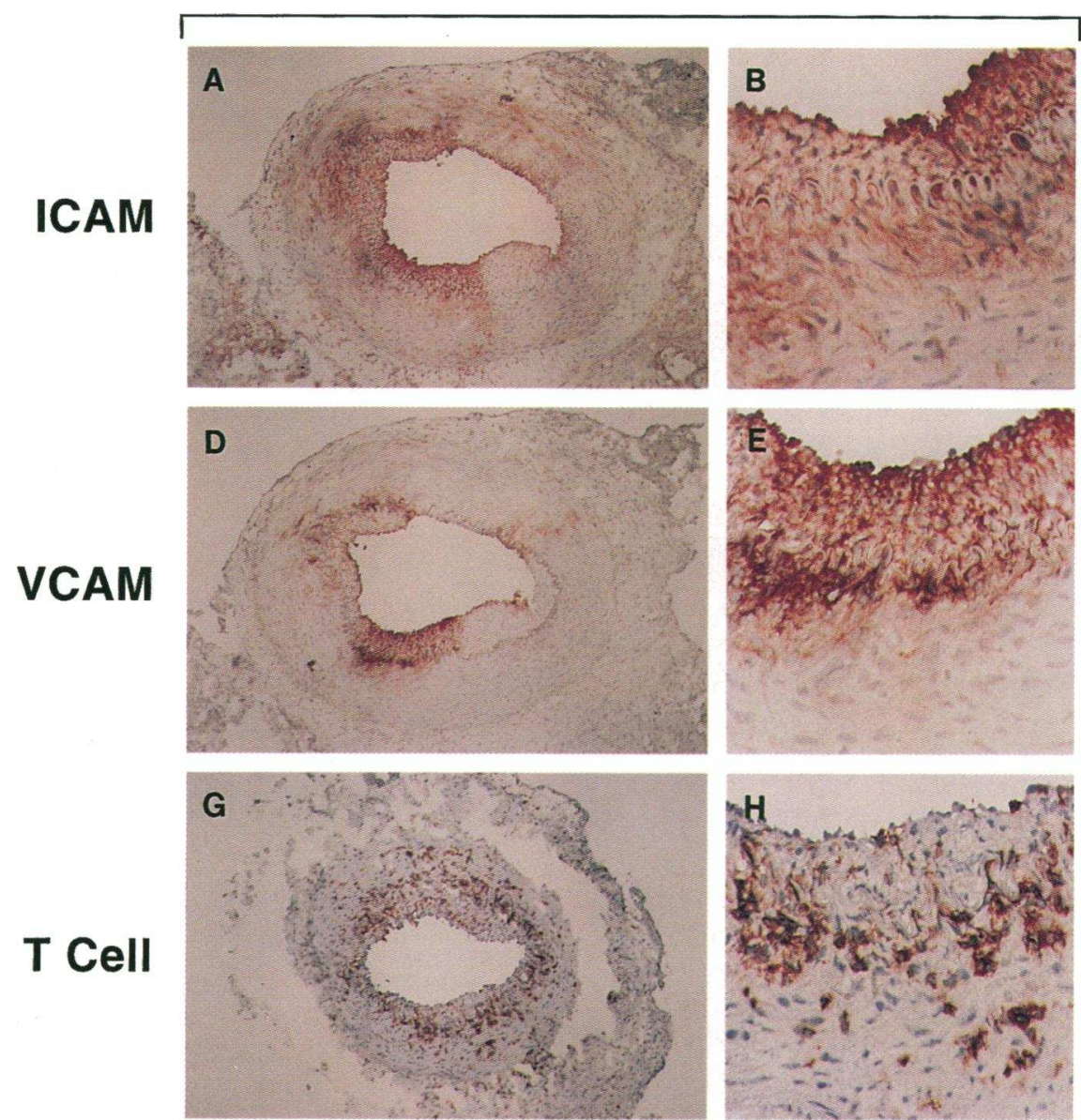

Control
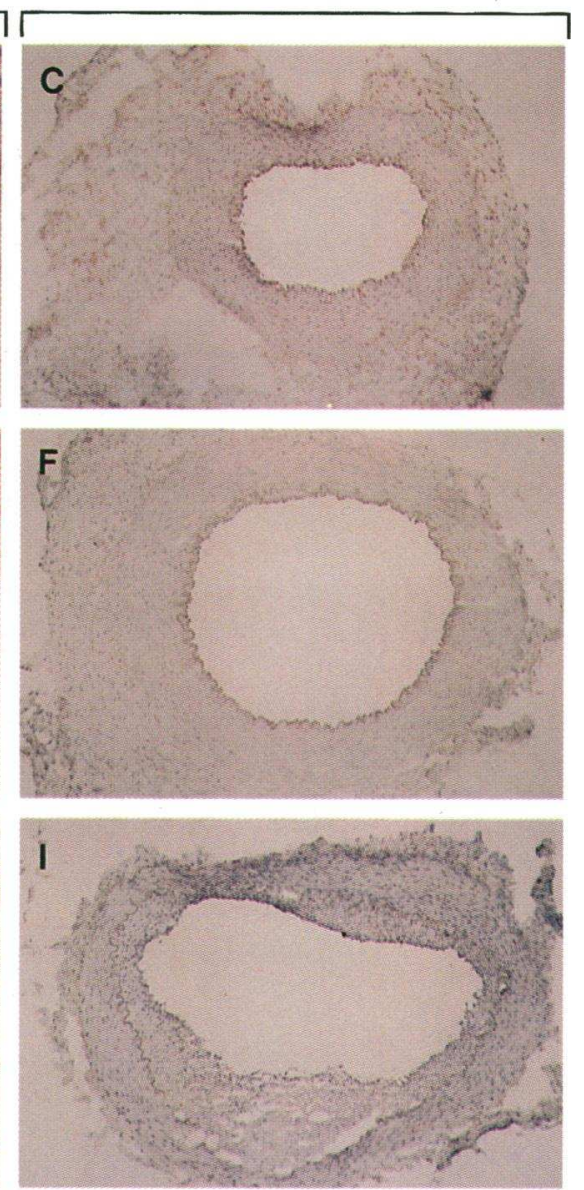

Figure 3. Increased expression of ICAM-1, VCAM-1, and increased T cell infiltration in rabbit femoral arteries $10 \mathrm{~d}$ after exposure to Av1LacZ4. Staining is for ICAM-1 $(A-C)$; VCAM-1 $(D-F)$; T cells $(G-I)$. Infusates are indicated at top; virus-infused vessels were all infused with Av1LacZ4 $(A, B, D, E, G$, and $H)$. Control vessels were infused with virus diluent $(C, F$, and $I)$. Original magnifications: 25 ( $A$, $C, D, F, G$, and $I) ; 100(B, E$, and $H)$.

vessels and zero of four controls contained cells staining positively for nuclear-localized $\beta$-Gal. The number of transduced endothelial cells per histologic section was $1.8 \pm 0.6$, and the number of transduced SMC per section was $8 \pm 1.7$ (Fig. $2 D$ ).

Six of seven vessels exposed to Av1LacZ4 and harvested $30 \mathrm{~d}$ after gene transfer were patent; seven of seven matched control vessels were patent. On gross examination, there was no evidence of recombinant gene expression in either the experimental or the control vessels. On microscopic examination, there were rare transduced medial SMC in the experimental vessels. There were no transduced intimal cells in the experimental vessels, and no transduced cells at all in the control vessels. Thus, in agreement with previous reports of adenovirusmediated gene transfer into the arteries of adult animals $(6,7$, $9,11)$, recombinant gene expression in this animal model was transient and was essentially undetectable by 4 wk.

Vascular cell activation and inflammation after exposure to adenovirus. To test the hypothesis that adenovirus-mediated gene transfer results in inflammation and activation of the cells of the arterial wall, we performed immunohistochemical staining for ICAM-1, VCAM-1, MHC-II, macrophages, and T cells on frozen sections of arteries harvested 3,10 , and $30 \mathrm{~d}$ after gene transfer (Figs. 3, 4, and data not shown). Our initial exami- nation of 3-d sections revealed considerably less positive staining than in 10- and 30-d sections; therefore, our analyses were confined to the 10- and 30-d sections. At $10 \mathrm{~d}$, intense areas of positive staining for ICAM-1, VCAM-1, and T cells were present in both the neointima and the media of vessels infused with Av1LacZ4 (Fig. 3). Staining intensities were approximately equal in the media and developing neointima. Semiquantitative analysis of sections from both experimental and control vessels revealed significantly increased staining for all three of these markers of vascular activation (Fig. $5 A ; P<0.05$ for each; Mann-Whitney $U$ test). The mean score for ICAM-1 was $2.7 \pm 1.2$ in the experimental vessels and $0.56 \pm 0.51$ in the controls. Intensity of VCAM-1 staining was $2.3 \pm 0.87$ in the experimentals and was not detectable in sections from control vessels (zero for all sections). Because ICAM-1 and VCAM-1 staining was largely confined to the media and neointima, and because macrophages were rare in all sections (typically zero or one macrophage per section), we presume that ICAM-1 and VCAM-1 expression was primarily from vascular SMC.

We also stained frozen sections for the presence of $\mathrm{T}$ cells, macrophages, and MHC-II. The intensity of T cell staining was graded as $3.1 \pm 0.84$ in vector-infused vessels, and $0.44 \pm 0.77$ in the controls. There was also a small, statistically insignificant 

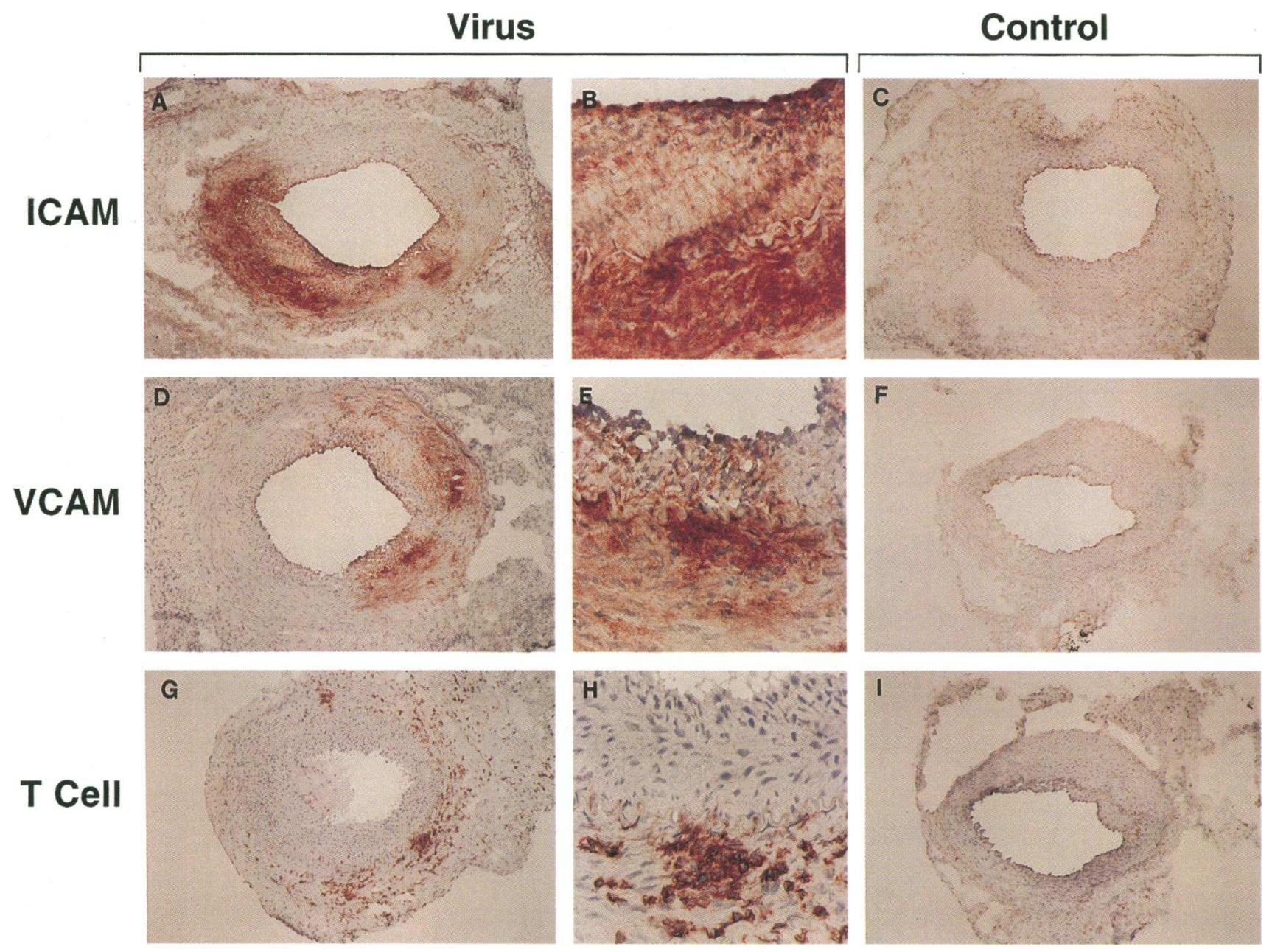

Figure 4. Increased expression of ICAM-1, VCAM-1, and increased $\mathrm{T}$ cell infiltration in rabbit femoral arteries $30 \mathrm{~d}$ after exposure to adenovirus. Staining is for ICAM-1 $(A-C)$; VCAM-1 $(D-F)$; T cells $(G-I)$. Infusates are indicated at top; virus-infused vessels were infused with Av1LacZ4 $(G$ and $H)$ or Av1Nu12 $(A, B, D$, and $E)$. Control vessels were infused with virus diluent $(C, F$, and $I)$. Original magnifications: 25 ( $A, C, D, F$, $G$, and $I) ; 100(B, E$, and $H)$.

increase in staining for macrophages in experimental versus control vessels $(0.78 \pm 1.3$ vs 0$)$. The intensity of staining for MHC-II expression did not differ between experimental and control vessels $(2.0 \pm 0.89$ vs $2.3 \pm 1.4)$. Control sections taken from nonmanipulated segments of abdominal aorta (stained in parallel with the experimental and control femoral arteries) did not have detectable staining for any of the five markers (not shown).

Immunohistochemical staining for inflammatory cells and for markers of vascular activation was repeated with sections taken from femoral arteries harvested $30 \mathrm{~d}$ after infusion of either Av1LacZ4 or either of the two control solutions (see Methods). Similar to the findings at $10 \mathrm{~d}$, staining for ICAM1, VCAM-1, and T cells was strongly positive in the Av1LacZ4infused arteries. At $30 \mathrm{~d}$, staining was present predominantly in the media rather than the neointima and was most often focal rather than diffuse (for example, Fig. $3 D$ and Fig. $4 A$ ). There was minimal staining in the control vessels. Semiquantitative analysis of stained sections revealed that ICAM-1, VCAM-1, and $T$ cell immunoreactivity were significantly increased in Av1LacZ4-infused arteries (Fig. $5 B ; P<0.05$ for each of the three markers; Mann-Whitney U test). Mean staining intensities for experimental and control vessels were: ICAM-1, 2.5 \pm 1.0 vs $0.24 \pm 0.34$; VCAM- $1,1.8 \pm 1.0$ vs 0 ; $\mathrm{T}$ cells, $2.8 \pm 1.2$ vs 0 ). Again, similar to the findings at $10 \mathrm{~d}$, there was a slight (but not statistically significant) increase in histochemical staining for macrophages in experimental vessels $(0.58 \pm 0.73$ vs 0 in controls). In contrast to the 10-d findings, MHC-II expression was significantly increased in Av1LacZ4-transduced vessels (3.0 \pm 0.6 vs $1.6 \pm 0.4 ; P<0.05$; Mann-Whitney U test).

The immunohistochemical study was repeated at the 30-d time point using Av1Nul2. Femoral arteries infused with Av1Nul2 and harvested at $30 \mathrm{~d}$ stained prominently for ICAM-1, VCAM-1, and T cells (Fig. 4, and data not shown). Semiquantitative analysis of histologic sections taken from Av1Nul2 and control-infused vessels revealed significant increases in staining for ICAM-1, VCAM-1, and T cells (Fig. $5 C$; $P<0.05$ for each comparison; Mann-Whitney $U$ test). Mean scores from experimental and control vessels were: ICAM-1, $2.5 \pm 1.8$ vs $0.42 \pm 0.84$; VCAM- $1,2.3 \pm 1.8$ vs 0 ; and $T$ cells, $3.2 \pm 1.0$ vs $0.12 \pm 0.14$. Av1Nul2-infused vessels had levels of staining that were slightly increased above those of control-infused vessels for both macrophages $(0.33 \pm 0.47$ vs 0$)$ and MHC-II expression $(1.7 \pm 1.5$ vs $1.1 \pm 0.92)$; these differences were not statistically 

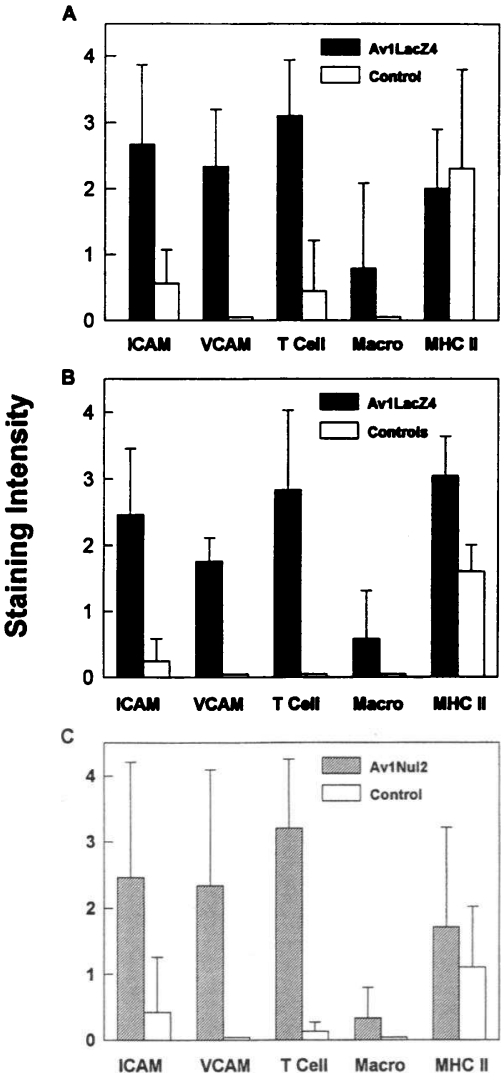

Figure 5. Intensity of histochemical staining for detection of ICAM-1 expression, VCAM-1 expression, $T$ cell infiltration, macrophage infiltration, and MHC-II expression. See Methods for description of 0-4 intensity scale. $(A)$ Vessels harvested $10 \mathrm{~d}$ after infusion of either Av1LacZA or control solution $(n=$ 4 vessels for each group). (B) Vessels harvested $30 \mathrm{~d}$ after infusion of either Av1LacZ4 or control solutions $(n=7$ vessels for each group). $(C)$ Vessels harvested 30 d after infusion of either Av1Nu12 or control solution ( $n=4$ vessels for each group). The heights of the bars represent mean values calculated from the values of the individual vessels in each group; error bars indicate standard deviations. Mean values of 0 are shown as bars of minimal height, without error bars.

significant. Sections taken from nonmanipulated segments of abdominal aorta were again included as controls. As was found in the rabbits infused with Av1LacZ4, there was no detectable staining of sections from uninjured aortas with any of the five antibodies (not shown).

To determine whether ICAM-1 and VCAM-1 were upregulated only in adenovirus-infected cells, serial frozen sections were taken from three arteries harvested $10 \mathrm{~d}$ after gene transfer. These serial sections were stained for $\beta$-Gal expression as well as for ICAM-1, VCAM-1, and T cells (Fig. 6). Expression of ICAM-1 and VCAM-1 was not limited to cells that stained blue with X-Gal. ICAM-1 - and VCAM-1-expressing cells were distributed both in the vicinity of transduced cells as well as in other areas of the artery. Staining for $T$ cells revealed that ICAM-1 and VCAM-1 expression colocalized far more closely with $\mathrm{T}$ cells than with the $\beta$-Gal-expressing cells.

Infusion of $U V$-inactivated virus. Four arteries infused with UV-inactivated Av1LacZ4 were harvested at $10 \mathrm{~d}$. Frozen sections (three per vessel for each stain) were either stained for $\beta$-Gal expression with X-Gal, or immunostained for ICAM-1, VCAM-1, and T cells. There was no $\beta$-Gal expression in any of the vessels, consistent with UV inactivation of vector gene expression. Sections stained for ICAM-1, VCAM-1, and T cells were graded for staining intensity, as described above. A mean staining score for each vessel was determined, and this score was used to rank all four vessels for staining intensity along with sections for four arteries that were infused with non-UVinactivated virus and also harvested at $10 \mathrm{~d}$. The mean intensities of staining for ICAM-1, VCAM-1, and T cells in arteries infused with UV-inactivated virus were: $1.8 \pm 0.50,0.75 \pm 0.96$, and $1.5 \pm 0.58$, whereas the mean intensities in arteries infused with non-UV-inactivated virus were $3.0 \pm 1.1,2.5 \pm 0.58$, and $3.5 \pm 0.58$. Statistical analysis revealed that each of these three markers of vascular activation was significantly less prominent in arteries infused with UV-inactivated virus $(P<.05$, MannWhitney U test).

Measurement of intimal/medial area ratios in vessels exposed to adenovirus. As an additional measure of the effects of adenovirus on the activation of the arterial wall, we examined perfusion-fixed arteries harvested both at 10 and $30 \mathrm{~d}$ for the presence of a neointima (Figs. 7 and 8 ). The presence of a neointima was far more common in virus-infused than in control-infused arteries (compare Fig. $7 A$ and $B$ to Fig. $7 C$ and $D)$. To test for the presence of significant differences in intimal/ medial area ratios, quantitative analysis was performed of the intimal and medial areas of arteries infused with Av1LacZ4, Av1Nul2, or control solutions (Fig. 8). In arteries harvested at $10 \mathrm{~d}$, the mean intimal/medial area ratio in the Av1LacZ4exposed vessels was increased by fivefold compared to the control vessels $(0.20 \pm 0.19$ vs $0.037 \pm 0.08)$; however, this difference fell short of statistical significance ( $P=0.08$; Student's $t$ test; Fig. 7). In vessels harvested at $30 \mathrm{~d}$, the mean intimal/ medial area ratio for all Av1LacZ4-exposed vessels $(n=13)$ was increased fourfold over those in the pooled control groups $(n=13): 0.64 \pm 0.35$ vs $0.15 \pm 0.17, P<0.008$. If the two control groups were compared separately, significant $3-10$-fold differences were still found: $0.7 \pm 0.43$ vs $0.06 \pm 0.02, P<0.005$ for the virus diluent controls $(n=6) ; 0.59 \pm 0.3$ vs $0.24 \pm 0.20$, $P=0.02$ for the diluted virus storage buffer controls $(n=7)$.

To determine whether the observed effect of Av1LacZ4 on neointima formation was due to the virus or to the $\beta-\mathrm{Gal}$ transgene, an additional group of four rabbits was infused with Av1Nul2 and appropriately diluted virus storage buffer. All vessels were harvested $30 \mathrm{~d}$ after gene transfer. The mean inti$\mathrm{mal} / \mathrm{medial}$ area ratio for the Av1Nul2-infused vessels was increased by 10 -fold over that of vessels infused with control solution $(0.67 \pm 0.12$ vs $0.063 \pm 0.06 ; P<0.005$; Student's $t$ test). Thus, exposure to adenovirus resulted in the observed neointimal hyperplasia.

Inflammation and neointima formation in transduced rat arteries. In uninjured rat carotid arteries transduced with Av1LacZA, there was very little neointima present at both 14 and $28 \mathrm{~d}$; intimal/medial area ratios were 0.1 and below (data not shown; compare to Fig. 8). Also in contrast to the findings with rabbit arteries, there was no medial $\mathrm{T}$ cell infiltrate present in any of the rat arteries. Rare $\mathrm{T}$ cells were seen on the luminal surface of the artery, in the neointima, and in the adventitia: zero to three cells per section (not shown; compare Fig. 3, $G$ and $H$ and Fig. 4, $G$ and $H$ ). We did not stain for ICAM-1 and VCAM-1 expression due to a lack of specific antisera directed against the rat proteins. Thus our findings of infiltration and intimal hyperplasia consequent to adenovirus gene transfer may have a degree of species specificity.

\section{Discussion}

The major findings of this study are that adenovirus-mediated gene transfer into surgically exposed normal rabbit femoral arteries results in: $(a)$ efficient, relatively endothelial-specific gene transfer with transient (essentially $<10 \mathrm{~d}$ ) recombinant gene expression; $(b)$ prolonged ( $\geq 30$ days) activation of vas- 

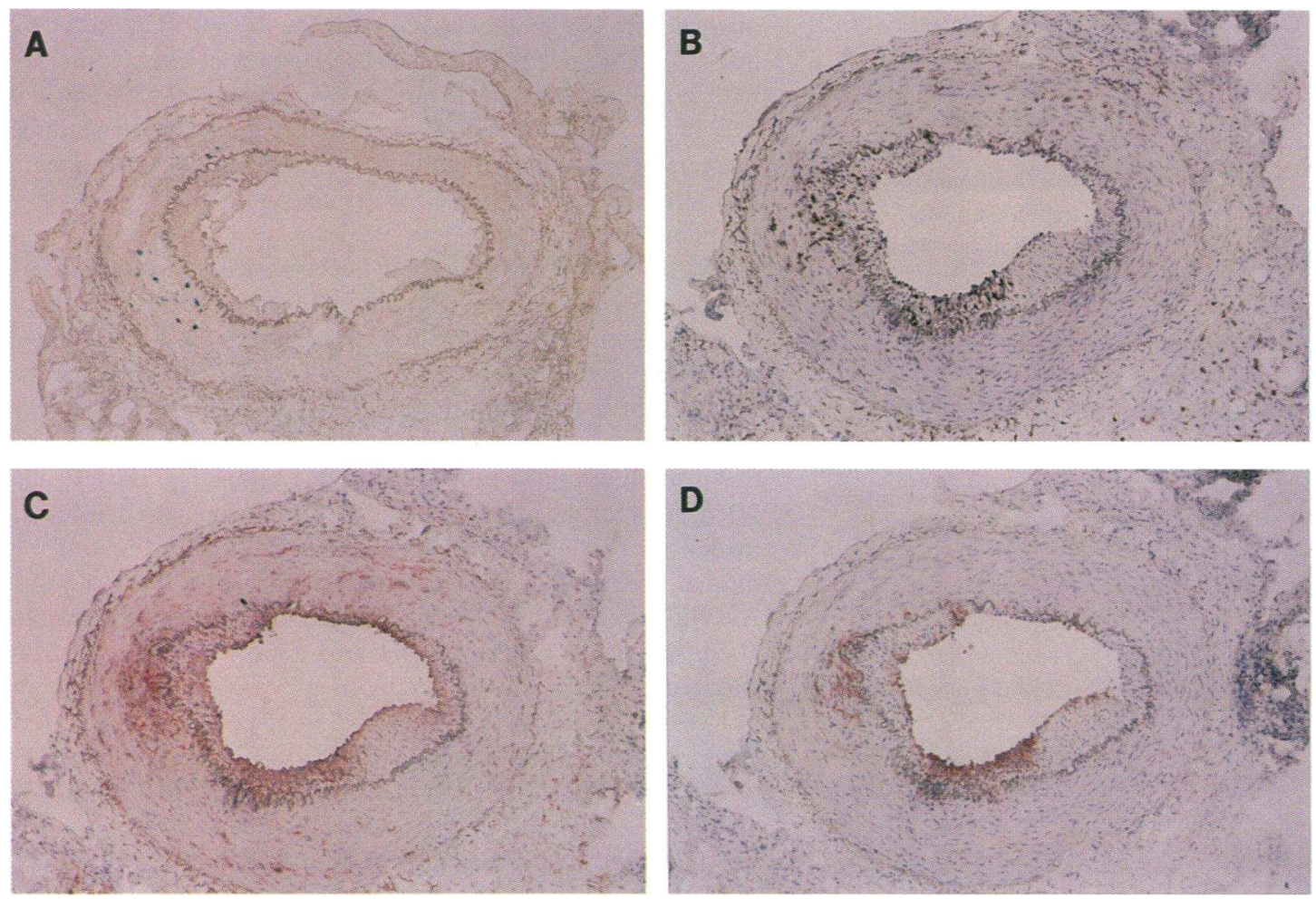

Figure 6. Location of transduced cells relative to markers of vascular cell activation. Serial 5- $\mu \mathrm{M}$ thick frozen sections were taken from an artery harvested $10 \mathrm{~d}$ after infusion with Av1LacZA and stained for: $(A) \beta$-Gal, $(B)$ T cells, $(C)$ ICAM-1, and $(D)$ VCAM-1. ICAM-1 and VCAM-1 expression colocalize with areas of T cell infiltration. ICAM-1 and VCAM-1 expression does not colocalize exclusively with $\beta$-Gal-expressing cells. Variability in morphology of $(A)$ versus $(B-D)$ is due to differences in tissue processing protocols for X-gal staining versus immunostaining with counterstain. Original magnifications $\times 25$; hematoxylin counterstain in B-D.

cular SMC, as manifested by increased expression of the adhesion molecules ICAM-1 and VCAM-1; $(c)$ prolonged $(\geq 30$ days) $\mathrm{T}$ cell infiltration into the media and neointima; and $(d)$ significantly increased neointima formation.

We used rabbit arteries to attempt to delineate possible detrimental effects of replication-defective adenovirus vectors on the arterial wall. The rabbit was chosen because of its utility as an animal model of vascular disease (30). It is likely that future studies using adenovirus-mediated gene transfer both to study and to treat vascular disease will be carried out in rabbits $(8$, 11); therefore, a study defining the baseline effects of adenovirus vectors in this species is appropriate. We used "normal" rabbit arteries, not subjected to intentional injury, for two reasons: $(a)$ to minimize animal-to-animal variability and $(b)$ to increase the sensitivity of our assays to detect the three experimental endpoints of vascular cell activation, inflammation, and neointima formation by looking for these features in normal arteries, in which they are not usually present. We did not extend this study to diseased arteries because expected high background levels of vascular activation $(22,31,32)$ and recently reported low gene transfer efficiency (33) render studies in diseased arteries problematic.

Infusion of replication-defective adenovirus (with and without an inserted $\beta$-Gal transgene) resulted in enhanced vascular SMC expression of ICAM-1 and VCAM-1. While the precise roles of these adhesion molecules in the vessel wall are not yet clear (23), vascular expression of ICAM-1 and VCAM-1 is strongly associated with arterial pathology in both animals and humans. When expressed by vascular endothelium, ICAM-1 and VCAM-1 are believed to participate in the adhesion and consequent entry of mononuclear leukocytes into the arterial wall (34). In experimental atherosclerosis in rabbits, increases in endothelial VCAM-1 expression are among the earliest vascular changes, preceding monocyte infiltration $(31,32)$. Increased SMC expression of ICAM-1 and VCAM-1 is also associated with both established and evolving vascular disease, though the precise role of SMC adhesion molecule expression is less well understood. In balloon-injured rabbit aortas, both ICAM-1 and VCAM-1 are upregulated in SMC (22). Enhanced expression of both ICAM-1 and VCAM-1 has also been reported in SMC within human atherosclerotic lesions (35-37). Thus, in both rabbit and human studies, ICAM-1 and VCAM1 are viewed as either markers of, or actual participants in, the development of arterial pathology.

In view of their association with arterial disease, the prolonged and prominent expression of ICAM-1 and VCAM-1 after exposure of normal rabbit arteries to adenovirus has important implications for those who use adenovirus as a tool for treating or understanding vascular disease. For example, experiments attempting adenovirus-mediated overproduction of soluble VCAM-1 as a therapeutic strategy (38) might be confounded by enhanced production of endogenous, cell-associated VCAM-1. In a hypothetical experiment in which arterial infusion of an adenovirus vector expressing monocyte chemotactic protein-1 results in monocyte infiltration, a conclusion that monocyte chemotactic protein-1 is uniquely responsible for this finding might not be justified. A direct contribution of the vector itself to monocyte infiltration, through upregulation of adhesion 

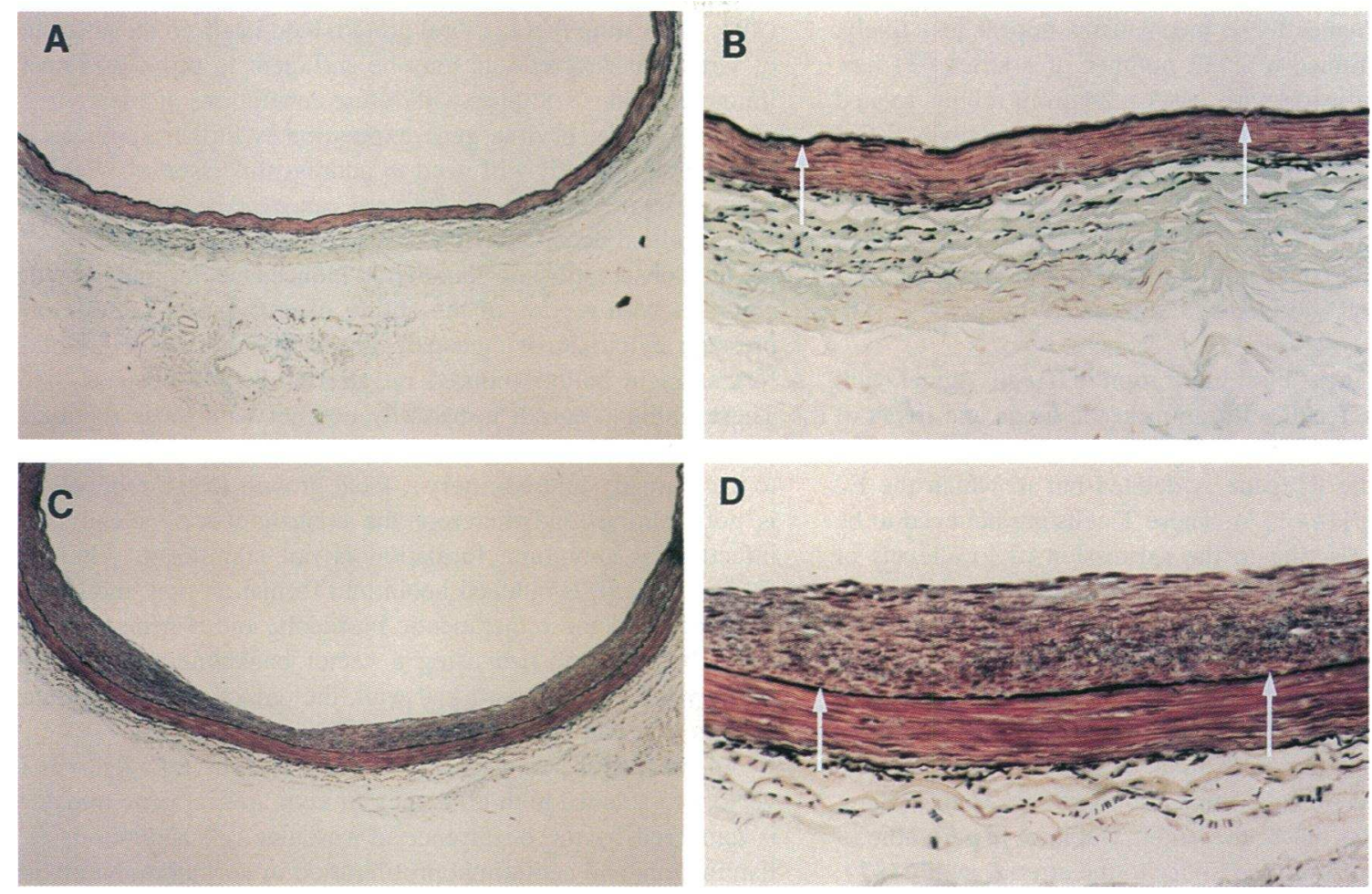

Figure 7. Neointima formation in rabbit femoral arteries infused with adenovirus. $(A$ and $B)$ Low and high power views of artery infused with control solution. ( $C$ and $D$ ) Low and high power views of artery infused with Av1LacZA. Demarcation of the internal elastic lamina (indicated with arrows in $B$ and $D$ ) reveals the presence of a significant neointima in the Av1LacZ4-infused vessel. All panels: Movat's pentachrome stain. Original magnifications: $A$ and $C, \times 25 ; B$ and $D, \times 100$.

molecules, would require consideration and specific experimental evaluation.

The route by which exposure to adenovirus results in upregulation of SMC ICAM-1 and VCAM-1 is not clear; however,

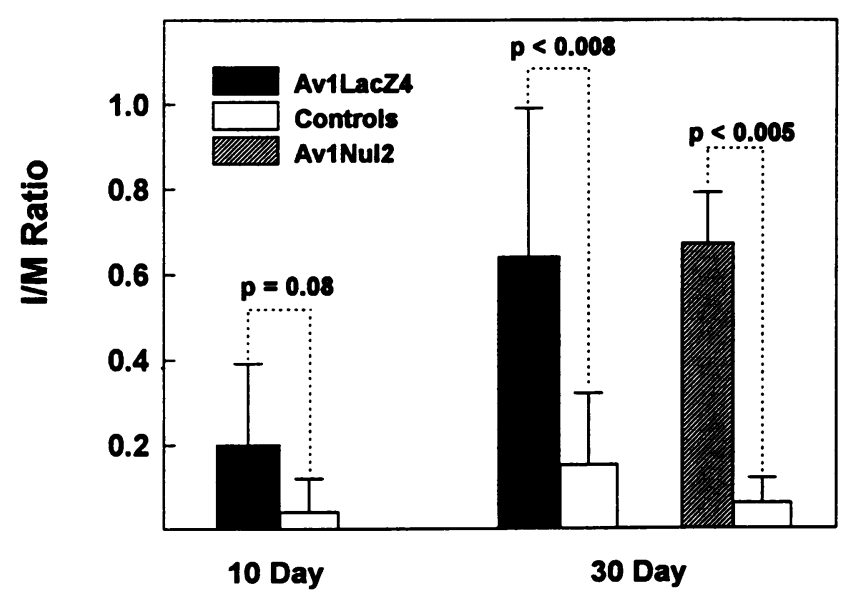

Figure 8. Intimal/medial $(I / M)$ ratios in arteries exposed to Av1LacZ4, Av1Nul2, or control infusates. The number of days after infusion on which the vessels were harvested is indicated. Vessels infused with Av1LacZ4 (and contralateral control vessels) were harvested at day 10 $(n=6)$ and day $30(n=6)$. Vessels infused with Av1Nul2 (and contralateral control vessels) were harvested at day $30(n=7)$. The heights of the bars represent mean values calculated from the I/M ratios of the individual vessels in each group; error bars indicate standard deviations. the patterns of staining for ICAM-1, VCAM-1, T cells, and $\beta$ galactosidase in tissue sections do provide some mechanistic clues. The differing time courses of expression of $\beta$-Gal (peak at $3 \mathrm{~d}$ ) and ICAM-1/VCAM-1 (maximal at 10-30 d) precluded staining optimally for both $\beta$-Gal and ICAM-1/VCAM-1 expression in the same arteries. However, staining of serial frozen sections taken from three arteries $10 \mathrm{~d}$ after gene transfer revealed that ICAM-1 and VCAM-1 expression colocalized with areas of $\mathrm{T}$ cell infiltration far more closely than with areas of $\beta$-Gal expression. In addition, ICAM- 1 and VCAM- 1 expression were present in considerably more cells than stained positively with X-Gal (Fig. 6). While we cannot exclude the presence of $\beta$-Gal expression at levels too low to detect in those SMC expressing ICAM-1 and VCAM-1 (39), our data suggest that ICAM-1 and VCAM-1 expression are upregulated in SMC not by direct infection but rather by exposure to $T$ cell-derived cytokines. In support of this hypothesis are reports of the upregulation of ICAM-1 and VCAM-1 by T cell-derived cytokines such as IL-4 (40), IL-1, and TNF (34).

Two other mechanisms for the observed upregulation of SMC ICAM-1 and VCAM-1 are: $(a)$ a primary effect of adenovirus on adhesion molecule expression in infected SMC (as reported consequent to expression of hepatitis $\mathrm{B} X$ protein in cultured human hepatoma cells [41] or after herpes simplex virus-1 infection of endothelial cells [42]); (b) upregulation of cytokine expression in adenovirus-infected SMC with consequent cytokine-induced adhesion molecule expression (similar to the reported induction of IL-8 expression by adenovirus infection of airway epithelial cells in vitro [43]). The preferential localization of ICAM-1 and VCAM-1 expression to areas of 
T cell infiltration makes these mechanisms appear less likely. Moreover, we examined a small number of arteries (3) harvested $10 \mathrm{~d}$ after infusion with Av1LacZ4 from rabbits treated with cyclosporine A ( $15 \mathrm{mg} / \mathrm{kg}$ subcutaneously, daily). $\beta-\mathrm{Gal}$ expression in these arteries was at least as high as in arteries taken from rabbits not treated with cyclosporine A; however, arterial $\mathrm{T}$ cell infiltrates, ICAM-1, and VCAM-1 expression were noticeably less (data not shown). These data support a central role for $\mathrm{T}$ cell-derived cytokines in the observed vascular cell activation.

The prominent intramural infiltration of $T$ cells agrees with previous reports of $\mathrm{T}$ cell infiltration in the lungs and livers of mice exposed to "first generation" adenovirus vectors (i.e., vectors in which the E1 gene is deleted but in which the E2 gene remains intact $[16-18]$ ). These $T$ cells are believed to be cytotoxic $\mathrm{T}$ cells, reacting to the expression of low levels of adenoviral proteins by infiltrating tissues and eliminating transduced cells (16). Again, as with ICAM-1 and VCAM-1 expression, the presence of the T cell infiltrate should prompt a reevaluation of the use of current adenovirus vectors for both biological and therapeutic experiments. Specifically, gene transfer experiments designed to model, treat, or prevent atherosclerosis will be complicated by superimposition upon an acute inflammatory process. If, as has been written, "at least in part, atherosclerosis is a form of immune injury to the arterial wall" (37), this "immune injury" will be most appropriately studied and treated in the absence of the acute inflammatory disease that results from exposure to adenovirus.

Our finding of increased neointima formation was unanticipated in light of current attempts to use adenovirus vectors to prevent arterial proliferative disease $(2-4)$. The stimulus for neointimal growth that results from adenovirus exposure is not clear, but could include direct mitogenic effects of the virus or indirect effects via infiltrating $T$ cells. Of note, $T$ cells can synthesize factors that stimulate growth of vascular cells and fibroblasts, including basic fibroblast growth factor and heparinbinding epidermal growth factor-like growth factor $(44,45)$. Our finding of intimal hyperplasia is similar to a recent report of inflammatory infiltrates, reactive hyperplasia, and squamous metaplasia in the tracheas of adenoviral vector-infected fetal lambs (46), and suggests that adenovirus-related tissue remodeling is not limited to blood vessels. In addition, this recent report, as well as previous reports of prolonged (at least $2 \mathrm{mo}$ ) inflammation in the lungs of primates exposed to adenovirus vectors $(47,48)$, suggests that the pathogenic effects of adenovirus vector exposure that we describe are not limited to rabbits. Attempts to introduce first generation adenovirus vectors into the human vasculature should take into account the possibility that arterial pathology similar to that described herein might be produced.

Our results with UV-inactivated virus indicate that improvements in vector design that decrease virus gene expression may lessen vascular activation consequent to adenovirus gene transfer. UV-inactivated virus serves as a model of future generations of adenovirus vector that may eventually mediate efficient gene transfer with no viral gene expression. It is notable that although use of the UV-inactivated virus resulted in decreased inflammation and vascular activation, the intensity of staining for ICAM1, VCAM-1, and T cells in arteries infused with UV-inactivated virus was still above that present in arteries infused with vehicle only. Our data are in agreement with the recent data of Yang et al., who infused UV-inactivated adenovirus into mouse lungs
(49), suggesting that the viral protein load itself, in the absence of virus gene expression, may be sufficient to provoke a host immune response. Studies with future generations of adenovirus vectors (in which virus gene expression is further suppressed or even eliminated) will need to address this issue of whether adenovirus-mediated gene delivery can ever be accomplished with minimal accompanying tissue inflammation.

Our observation of adenovirus-induced neointimal growth contrasts with reports of the ability of adenovirus vectors expressing cytotoxic or cytostatic genes to suppress neointimal formation in balloon-injured rat arteries by $40-50 \%(2-4)$. These findings do not necessarily conflict with those reported herein. It is possible that in a balloon-injured artery (as opposed to a minimally injured artery), local growth factor production is not limiting, and therefore the contribution of adenovirus infection to neointima formation is not significant. Alternatively, adenovirus-induced neointima formation may moderate the success of these therapeutic protocols, and if gene transfer could be accomplished using a vector backbone that had no primary effects on the arterial wall, the reduction in neointima formation might approach $100 \%$.

In conclusion, we demonstrate that the ability of adenovirus vectors to achieve high efficiency in vivo arterial gene transfer is tempered by the occurrence of vascular cell activation, inflammation, and neointimal proliferation in normal rabbit arteries. Efforts at vector development should be directed at minimizing these effects so that the potential of adenovirus vectors to serve as investigational and therapeutic tools in vascular biology may be realized.

\section{Acknowledgments}

We thank Robert Hoyt, D.V.M., John DeLeonardis, and Randy Clevenger from the Laboratory of Animal Medicine and Surgery for excellent assistance with animal surgery. Michael A. Eckhaus, D.V.M., and the Veterinary Resources Program of the National Center for Research Resources as well as Poonam Mannan of the Armed Forces Institute of Pathology provided invaluable technical assistance with the immunohistochemistry protocols. We thank Dr. Myron Cybulsky for providing antibodies to rabbit ICAM-1 and VCAM-1, and Dr. Stephen G. Young for his careful review of the manuscript.

\section{References}

1. Nabel, E. G., and G. J. Nabel. 1994. Complex models for the study of gene function in cardiovascular biology. Annu. Rev. Physiol. 56:741-761.

2. Ohno, T., D. Gordon, H. San, V. J. Pompili, M. J. Imperiale, G. J. Nabel, and E. G. Nabel. 1994. Gene therapy for vascular smooth muscle cell proliferation after arterial injury. Science (Wash. DC). 265:781-784.

3. Guzman, R. J., E. A. Hirschowitz, S. L. Brody, R. Crystal, S. E. Epstein, and T. Finkel. 1994. In vivo suppression of injury-induced vascular smooth muscle cell accumulation using adenovirus-mediated transfer of herpes simplex thymidine kinase gene. Proc. Natl. Acad. Sci. USA. 91:10732-10736.

4. Chang, M. W., E. Barr, J. Seltzer, J. Yue-Qin, G. J. Nabel, E. G. Nabel, M. S. Parmacek, and J. M. Leiden. 1995. Cytostatic gene therapy for vascular proliferative disorders with a constitutively active form of the retinoblastoma gene product. Science (Wash. DC). 267:518-522.

5. von der Leyen, H. E. G. H. Gibbons, R. Morishita, N. P. Lewis, L. Zhang, M. Nakajima, Y. Kaneda, J. P. Cooke, and V. J. Dzau. 1995. Gene therapy inhibiting neointimal vascular lesion: In vivo transfer of endothelial cell nitric oxide synthase gene. Proc. Natl. Acad. Sci. USA. 92:1137-1141.

6. Lemarchand, P., M. Jones, I. Yamada, and R. G. Crystal. 1993. In vivo gene transfer and expression in normal, uninjured blood vessels using replication deficient recombinant adenovirus vectors. Circ. Res. 72:1132-1138.

7. Lee, S. W., B. C. Trapnell, J. J. Rade, R. Virmani, and D. A. Dichek. 1993. In vivo adenoviral vector-mediated gene transfer into balloon-injured rat carotid arteries. Circ. Res. 73:797-807.

8. Willard, J. E., C. Landau, D. B. Glamann, D. Burns, M. E. Jessen, M. J. 
Pirwitz, R. D. Gerard, and R. S. Meidell. 1994. Genetic modification of the vessel wall. Comparison of surgical and catheter-based techniques for delivery of recombinant adenovirus. Circulation. 89:2190-2197.

9. Guzman, R. J., P. Lemarchand, R. G. Crystal, S. E. Epstein, and T. Finkel. 1993. Efficient and selective adenovirus-mediated gene transfer into vascular neointima. Circulation. 88:2838-2848.

10. French, B. A., W. Mazur, N. M. Ali, R. S. Geske, J. P. Finnigan, G. P. Rodgers, R. Roberts, and A. E. Raizner. 1994. Percutaneous transluminal in vivo gene transfer by recombinant adenovirus in normal porcine coronary arteries, atherosclerotic arteries, and two models of coronary restenosis. Circulation. 5:2402-2413.

11. Steg, P. G., L. J. Feldman, J.-Y. Scoazec, O. Tahlil, J. J. Barry, S. Boulechfar, T. Ragot, J. M. Isner, and M. Perricaudet. 1994. Arterial gene transfer to rabbit endothelial and smooth muscle cells using percutaneous delivery of an adenoviral vector. Circulation. 90:1648-1656.

12. Graham, F. L., and L. Prevec. 1991. Manipulation of adenovirus vectors. In Methods in Molecular Biology, Vol. 7: Gene Transfer and Expression Protocols. E. J. Murray, editor. The Humana Press, Clifton, NJ. 109-128.

13. Kozarsky, K. F., and J. M. Wilson. 1993. Gene therapy: adenovirus vectors. Curr. Opin. Genet. \& Dev. 3:499-503.

14. Rome, J. J., V. Shayani, M. Y. Flugelman, K. D. Newman, A. Farb, R Virmani, and D. A. Dichek. 1994. Anatomic barriers influence the distribution of in vivo gene transfer into the arterial wall: modeling with microscopic tracer particles and verification with a recombinant adenoviral vector. Arterioscler. Thromb. 14:148-161.

15. Roessler, B. J., E. D. Allen, J. M. Wilson, J. W. Hartman, and B. L. Davidson. 1993. Adenoviral-mediated gene transfer to rabbit synovium in vivo. J. Clin. Invest. 92:1085-1092.

16. Yang, Y., F. A. Nunes, K. Berencsi, E. E. Furth, E. Gonczol, and J. M. Wilson. 1994. Cellular immunity to viral antigens limits E1-deleted adenoviruses for gene therapy. Proc. Natl. Acad. Sci. USA. 91:4407-4411.

17. Yang, Y., F. A. Nunes, K. Berencsi, E. Gonczol, J. F. Engelhardt, and J. M. Wilson. 1994. Inactivation of E2A in recombinant adenoviruses improves the prospect for gene therapy in cystic fibrosis. Nat. Genet. 7:362-369.

18. Engelhardt, J. F., X. Ye, B. Doranz, and J. M. Wilson. 1994. Ablation of E2A in recombinant adenoviruses improves transgene persistence and decreases inflammatory response in mouse liver. Proc. Natl. Acad. Sci. USA. 91:61966200 .

19. Hajjar, D. P. 1991. Viral pathogenesis of atherosclerosis: impact of molecular mimicry and viral genes. Am. J. Pathol. 139:1195-1211.

20. Nabel, E. G. 1995. Gene therapy for cardiovascular disease. Circulation. 91:541-548.

21. Schneider, M. D. and B. A. French. 1993. The advent of adenovirus. Circulation. 88:1937-1942.

22. Tanaka, H., G. Sukhova, S. Swanson, S. Clinton, P. Ganz, M. Cybulsky, and P. Libby. 1993. Sustained activation of vascular cells and leukocytes in the rabbit aorta after balloon injury. Circulation. 88:1788-1803.

23. Libby, P., and H. Li. 1993. Vascular cell adhesion molecule-1 and smooth muscle cell activation during atherogenesis. J. Clin. Invest. 92:538-539.

24. Schulick, A. H., G. Dong, K. D. Newman, R. Virmani, and D. A. Dichek 1995. Endothelium-specific in vivo gene transfer. Circ. Res. 77:475-485.

25. Schulick, A. H., K. D. Newman, R. Virmani, and D. A. Dichek. 1995. In vivo gene transfer into injured carotid arteries. Optimization and evaluation of acute toxicity. Circulation. 91:2407-2414.

26. Gown, A. M., A. M. Vogel, D. Gordon, and P. L. Lu. 1985. A smooth muscle-specific monoclonal antibody recognizes smooth muscle actin isozymes. J. Cell Biol. 100:807-813.

27. Jackson, S., T. M. Chused, J. M. Wilkinson, W. M. Leiserson, and T. J. Kindt. 1983. Differentiation antigens identify subpopulations of rabbit $T$ and $B$ lymphocytes. J. Exp. Med. 157:34-36.

28. Yoshimura, K., M. A. Rosenfeld, P. Seth, and R. G. Crystal. 1993. Adenovirus-mediated augmentation of cell transfection with unmodified plasmid vectors. J. Biol. Chem. 268:2300-2303.

29. Mann, H. B., and D. R. Whitney. 1947. On a test of whether one of two random variables is stochastically larger than the other. Ann. Math. Stat. 18:5060.
30. Gross, D. R. 1994. Animal models in cardiovascular research. Kluwer Academic Publishers, Boston. 560 pp.

31. Li, H., M. I. Cybulsky, M. A. Gimbrone, Jr., and P. Libby. 1993. An atherogenic diet rapidly induces VCAM-1, a cytokine-regulatable mononuclear leukocyte adhesion molecule, in rabbit aortic endothelium. Arterioscler. Thromb. 13:197-204

32. Cybulsky, M. I., and M. A. Gimbrone, Jr. 1990. Endothelial expression of a mononuclear leukocyte adhesion molecule during atherogenesis. Science (Wash. DC). 251:788-791.

33. Feldman, L. J., P. G. Steg, L. P. Zheng, D. Chen, M. Kearney, S. E. McGarr, J. J. Barry, J. F. Dedieu, M. Perricaudet, and J. M. Isner. 1995. Low efficiency of percutaneous adenovirus-mediated arterial gene transfer in the atherosclerotic rabbit. J. Clin. Invest. 95:2662-2671.

34. Bevilacqua, M. P. 1993. Endothelial-leukocyte adhesion molecules. Annu. Rev. Immunol. 11:767-804.

35. Printseva, O. Y., M. M. Peclo, and A. M. Gown. 1992. Various cell types in human atherosclerotic lesions express ICAM-1: further immunocytochemical and immunochemical studies employing monoclonal antibody 10F3. Am. J. Pathol. 140:889-896.

36. Poston, R. N., D. O. Haskard, J. R. Coucher, N. P. Gall, and R. R. JohnsonTidey. 1992. Expression of intercellular adhesion molecule-1 in atherosclerotic plaques. Am. J. Pathol. 140:665-673.

37. O'Brien, K. D., M. D. Allen, T. O. McDonald, A. Chait, J. M. Harlan, D. Fishbein, J. McCarty, M. Ferguson, K. Hudkins, C. D. Benjamin, et al. 1993. Vascular cell adhesion molecule-1 is expressed in human coronary atherosclerotic plaques: implications for the mode of progression of advanced coronary atherosclerosis. J. Clin. Invest. 92:945-951.

38. Chen, S., J. M. Wilson, and D. W. M. Muller. 1994. Adenovirus-mediated gene transfer of soluble vascular cell adhesion molecule to porcine interposition vein grafts. Circulation. 89:1922-1928.

39. Zabner, J., L. A. Couture, A. E. Smith, and M. J. Welsh. 1994. Correction of cAMP-stimulated fluid secretion in cystic fibrosis airway epithelia: efficiency of adenovirus-mediated gene transfer in vitro. Hum. Gene Ther. 5:585-593.

40. Li, H., M. I. Cybulsky, M. A. Gimbrone, Jr., and P. Libby. 1993. Inducible expression of vascular cell adhesion molecule-1 by vascular smooth muscle cells in vitro and within rabbit atheroma. Am. J. Pathol. 143:1551-1559.

41. Hu, K. Q., Y. Chang-Hong, and J. M. Vierling. 1992. Up-regulation of intercellular adhesion molecule 1 transcription by hepatitis $\mathrm{B}$ virus $\mathrm{X}$ protein Proc. Natl. Acad. Sci. USA. 89:11441-11445.

42. Etingin, O. R., R. L. Silverstein, and D. P. Hajjar. 1991. Identification of a monocyte receptor on herpesvirus-infected endothelial cells. Proc. Natl. Acad. Sci. USA. 88:7200-7203.

43. Amin, R., R. Wilmott, Y. Schwarz, B. Trapnell, and J. Stark. 1995. Replication-deficient adenovirus induces expression of interleukin-8 by airway epithelial cells in vitro. Hum. Gene Ther. 6:145-153.

44. Blotnick, S., G. E. Peoples, M. R. Freeman, T. J. Eberlein, and M. Klagsbrun. 1994. T lymphocytes synthesize and export heparin-binding epidermal growth factor-like growth factor and basic fibroblast growth factor, mitogens for vascular cells and fibroblasts: differential production and release by CD4+ and CD8+ T cells. Proc. Natl. Acad. Sci. USA. 91:2890-2894.

45. Ross, R. 1994. The role of T lymphocytes in inflammation. Proc. Natl. Acad. Sci. USA. 91:2879.

46. McCray, P. B., Jr., K. Armstrong, J. Zabner, D. W. Miller, G. A. Koretzky, L. Couture, J. E. Robillard, A. E. Smith, and M. J. Welsh. 1995. Adenoviralmediated gene transfer to fetal pulmonary epithelia in vitro and in vivo. J. Clin Invest. 95:2620-2632.

47. Simon, R. H., J. F. Engelhardt, Y. Yang, M. Zepeda, S. Weber-Pendleton, M. Grossman, and J. M. Wilson. 1993. Adenovirus-mediated gene transfer of the CFTR gene to lungs of nonhuman primates: toxicity study. Hum. Gene Ther. 4:771-780.

48. Brody, S. L., M. Metzger, C. Danel, M. A. Rosenfeld, and R. G. Crystal. 1994. Acute responses of non-human primates to airway delivery of an adenovirus vector containing the human cystic fibrosis transmembrane conductance regulator cDNA. Hum. Gene Ther. 5:821-836.

49. Yang, Y., Q. Li, H. C. J. Ertl, and J. M. Wilson. 1995. Cellular and humoral immune responses to viral antigens create barriers to lung-directed gene therapy with recombinant adenovirus. J. Virol. 69:2004-2015. 